\title{
Sex, Lies and Letters: A Sample of Significant Deceptions in the Freud-Jung Relationship
}

\author{
Martin S. Fiebert \\ California State University at Long Beach, Long Beach, USA. \\ Email: mfiebert@csulb.edu
}

Received April 14 $4^{\text {th }}, 2010$; revised May 12 $2^{\text {nd }}, 2010$; accepted May 15 ${ }^{\text {th }}, 2010$.

\begin{abstract}
This project focuses on an examination of the correspondence between and the writings of Sigmund Freud and Carl Jung. A core theme in their relationship has been identified as deception, which appears to be correlated with and perhaps the cause of the end of their association. Incidences of mistrust and distrust have been detailed and discussed.
\end{abstract}

Keywords: Freud/Jung Relationship, Minna Bernays, Early Psychoanalytic History

\section{Introduction}

Sigmund Freud and Carl Jung, seminal figures in the history of Psychology, have been the subject of much study and discussion. A good deal of it focuses on conceptual differences in their theoretical and psychotherapeutic approaches. Some is also related to their differing emphases on, and acceptance of, notions of the unconscious, religious experience, and parapsychological phenomena, among other areas. Jung, in his Memoirs [1], Ernest Jones [2] and Peter Gay [3] in their comprehensive biographies of Freud have discussed some of the personal issues that eventually led to the acrimonious break between the two men.

My research is based on an examination of Freud and Jung's writings, their correspondence with each other and colleagues, and the writings and published recollections of their acquaintances. I have identified a central theme, that of deception, that I argue is present throughout the Freud-Jung relationship. In my view, this pattern of deception fostered mistrust between them, and is likely correlated with, if not the cause of, their eventual break.

\section{Freud's Affair with Minna Bernays}

Jung wrote that in March of 1907, Minna Bernays told him of her sexual intimacy with Freud, her sister's husband. He specified that she "was very much bothered by her relationship with Freud and felt guilty about it. From her I learned that Freud was in love with her and that their relationship was indeed very intimate. It was a shocking discovery for me, and even now (May, 1957) I can recall the agony I felt at the time" [4].

Apparently Jung never told Freud of Bernays's declaration. In my view, the woman's revelation of the affair had a profound impact on aspects of the Freud-Jung relationship. In particular, I would argue that Freud's actions as related by Bernays influenced Jung's decision to begin an affair with Sabina Spielrein, one of his own patients. The fact that they never discussed the affair and its ramifications played a part in subsequent deceptions in which both Freud and Jung engaged during their mutual dream analyses while on route to America in 1909.

\section{Freud Suspects Jung of Anti-Semitism}

In August 1908, Freud communicated to Karl Abraham his suspicion that Jung harbored anti-Semitic feelings [5]. Freud did not confront Jung on this issue. But in August 1912, Freud wrote to Otto Rank [3] stating that Jung had problems with achieving an "integration of Jews and anti-Semites on the soil of Psychoanalysis." In his article of 1914, entitled "The History of the Psychoanalytic Movement,” Freud publicly chastised Jung for maintaining "certain prejudices with regard to race" [6].

\section{Jung's Affair with Sabina Spielrein}

I would argue that when Jung discovered that his mentor was having a secret, culturally forbidden affair with his sister-in-law, Minna Bernays, it stimulated and in effect sanctioned his growing desire for his patient and student, Sabina Spielrein. According to letters and entries in Spielrein's diary, Jung lied to both Freud and Spielrein's mother about his relationship with Sabina [7]. In 1909, Spielrein wrote to Freud and told him of her romance 
with Jung. Freud apparently did not take Spielrein's allegations seriously and seemed to accept Jung's explanation that Spielrein was emotionally disturbed. When Spielrein visited Vienna in 1912, she and Freud became close, and he then came to accept her version of the earlier episodes, but did not tell Jung of his knowledge of the affair or his view of it. In January of 1913, after his personal relationship with Jung had already deteriorated, Freud wrote to Spielrein, "Since [the time] I received the first letter from you, my opinion of him (Jung) has been greatly altered" [7].

\section{Mutual Dream Analyses}

Profound deceptions occurred during the dream analyses Freud and Jung conducted reciprocally during their voyage to America in August 1909. The dishonesty itself and Jung's intense reaction presaged the eventual ending of their professional relations and personal friendship.

In his interview with Billinsky [4], Jung recalled that "Freud had some dreams that bothered him very much. The dreams were about the triangle-Freud, his wife and his wife's younger sister. Freud had no idea I knew about the triangle and his intimate relationship with his sister-in-law. And so, when Freud told me about the dream.I asked (him) to tell me some of his personal associations. He looked at me with bitterness and said, 'I could tell you more but I cannot risk my authority!’” Jung commented in his MEMOIRS [1], "At that moment he lost it altogether. That sentence burned itself in my memory; and in it the end of our relationship was already foreshadowed.”

For his part Jung was also dishonest about revealing to Freud the meaning of his own dreams. He shared one dream in which he was exploring a house. Descending into a cellar he found an ancient vault containing two human skulls. Analyzing his dream, Freud saw a likely death wish and pressed Jung for his associations to the details. Jung thought his dream really referred to ideas on which he was working, about the collective unconscious. Fearing Freud's resistance to his theories, he lied and said the skulls represented those of his wife, Emma and her sister [1].

Jung's unwillingness to honestly explore the meaning of the two skulls in the dream was clearly a way of protecting his theories from criticism or attack. Jung's deception while seeking to mollify Freud, was additionally I believe, a subtle attempt to establish more honesty in communication by indirectly revealing his knowledge of Freud's affair. Freud, apparently unaware of Jung's knowledge and intent was according to Jung, "greatly relieved" by Jung's deceptive interpretation of the skulls.

\section{Another Triangle: Emma Jung, Sandor Ferenczi and Freud}

Freud and Jung were not alone in communicating dis- honestly. Jung's wife, Emma, and Sandor Ferenczi, a colleague of Freud and Jung's, also participated in various deceptions.

Emma Jung attempted, although unsuccessfully, to repair what she perceived to be a growing rift between her husband and Freud. On October 15, 1911, Emma wrote to Ferenczi asking whether he was aware of Freud's disapproval of her husband's latest work, and explicitly requested him not to mention her concerns to Freud [8]. On October 19, Ferenczi betrayed Emma's confidence by sending her letter to Freud with one of his own in which he wondered if Freud was angry with Jung because of the latter's interest in the occult and his revision of the libido theory [8].

Freud's answering letter spelled out the way he wanted Ferenczi to answer Mrs. Jung, asking him not to mention to her neither occultism nor the libido. Because in German the word for "strike" (to avoid) and "emphasize" are similar, Ferenczi misread Freud's letter and his instructions, and informed Emma Jung that her husband's current interests particularly troubled Freud. Ferenczi's error, which was probably inadvertent, led to Emma's secretly writing to Freud [9], Jung subsequently found evidence of that correspondence, and this in turn increased the mistrust between Freud and Jung and further intensified their scientific and professional differences.

\section{The "Kreuzlingen Gesture"}

Freud himself also inadvertently misled Jung, this time about his sudden visit, in May 1912, to Ludwig Binswanger in Kreuzlingen, Switzerland, about forty miles from Jung's house in Zurich. Freud did not specifically arrange to see Jung who was hurt and upset by what he thought was Freud's avoiding him. In later correspondence with Freud, Jung referred bitterly to this incident as the "Kreuzlingen gesture" [9].

In fact, two days before his departure, Freud wrote to both Jung and Binswanger and actually assumed that Jung would meet him in Kreuzlingen. However, Jung, out of town, did not receive Freud's note in time to make travel arrangements. More importantly, Jung was not apprised of the fact that the primary reason for Freud's visit was Binswanger's impending surgery for cancer $[3,10]$ because Binswanger had asked that the information not be shared. Thus, yet another minor and finally unnecessary secret contributed to the breakdown of the Freud-Jung relationship.

\section{The Committee}

In response to the growing tension and mistrust in the Freud-Jung relationship, and, in particular, to the intensity of Jung's reaction to the "Kreuzlingen gesture," Ernest Jones, a feisty and loyal supporter of Freud, initiated a grand deception which had profound implications for both the Freud-Jung relationship and the history of 
Psychoanalysis. In the summer of 1912, Jones suggested that a small group of trusted analysts form a kind of "palace guard" around Freud to protect him from future dissension. Freud warmly accepted this idea but cautioned, "The committee would have to be strictly secret in its existence and actions" [2]. The group consisted of Jones, Ferenczi, Rank, Sachs and Abraham, and for many years advised Freud and guided Psychoanalytic policy.

Although Jung was the elected president of the International Psychoanalytic Society and had earlier been designated by Freud as his "son and heir" [9], he was kept ignorant regarding the committee's existence and actions.

\section{Freud, Jung and Homophobia}

In a letter written on November 29, 1912, Freud tried to hide his homoerotic feelings for Jung. I believe this deception was a significant element in precipitating the end of their personal relationship. After Freud and Jung had apparently reconciled some of their theoretical differences during a conference in Munich on November 24, 1912, and had cleared up the misunderstanding concerning Freud's visit to Binswanger, Freud fainted, for the second time, in Jung's presence. Jung carried Freud over to a sofa. Two days later Jung wrote Freud a very friendly note, apologizing for earlier difficulties and inquiring after Freud's health [1,9]. Freud's response to Jung acknowledged some unresolved differences in their theoretical views, specifically on the libido. Then, referring to his fainting spell, he wrote, "according to my private diagnosis, it was migraine not without a psychic factor which unfortunately I haven't had time to track down a bit of neurosis I ought to look into” [9]. However, Freud was much more candid in a letter to Jones when he attributed his fainting spell to an "unruly homosexual feeling," which involved a transference of his earlier, intense friendship with Wilhelm Fliess to one with Jung [8].

Jung exploded with rage over Freud's letter and explanation of his loss of consciousness. He was angry both at Freud's downplaying the meaning of the faint, and at what he perceived as Freud's trivializing of Jung's contribution to Libido Theory [9]. I suspect that on another level Jung sensed Freud's homoerotic conflict, perhaps intensified by the physical contact created by his carrying Freud and was angered that Freud was dishonest about its significance.

It should be mentioned that Jung, himself, was particularly vulnerable to both homoerotic and homophobic feelings. Earlier in their relationship, in 1907, Jung had confessed to Freud that as a boy he had been homosexually assaulted by a man he trusted. He also admitted, when he asked Freud for his photograph, that he had "religious crush" on Freud which he was aware had "clear erotic undertones" [9].

After exchanging several angry letters with Jung, Freud waited two weeks and then on January 3, 1913 wrote, "I propose that we abandon our personal relations entirely” [9].

\section{REFERENCES}

[1] C. G. Jung, “Memories, Dreams, Reflections,” In: A. Jaffe, Ed., Vintage, New York, 1963.

[2] E. Jones, "Life and Work of Sigmund Freud," Basic Books, New York, 1953, 1955, 1957.

[3] P. Gay, "Freud: A Life for Our Time," Norton, New York, 1988.

[4] J. M. Billinsky, "Jung and Freud: The End of a Romance,” Andover Newton Quarterly, Vol. 10, No. 2, 1969, pp. 39-43.

[5] H. C. Curtis, "A Psychoanalytic Dialogue: The Letters of Sigmund Freud and Karl Abraham,” In: H. C. Abraham and E. L. Freud, Eds., Basic Books, New York, 1965, pp. 1907-1926

[6] S. Freud, "On the History of Psychoanalytic Movement," Collected Papers, Basic Books, New York, 1959.

[7] A. Carotenuto, "A Secret Symmetry: Sabina Spielrein between Jung and Freud,” Pantheon, New York, 1984.

[8] L. Donn, "Freud and Jung: Years of Friendship, Years of Loss,” Collier, New York, 1988.

[9] W. McGuire, "The Freud-Jung Letters: The Correspondence between Sigmund Freud and C. G. Jung. M. A,” Harvard University Press, Cambridge, 1974.

[10] L. Binswanger, "Sigmund Freud: Reminiscences of a Friendship,” Grune \& Stratton, New York, 1957. 